\title{
Opening doors: suggested practice for medical professionals for when a child might be close to telling about abuse
}

\author{
Ruth Marchant, ${ }^{1}$ Jamie Carter $\quad\left(10,{ }^{2}\right.$ Charlie Fairhurst $^{3}$
}

\begin{abstract}
SUMMARY
The way medical professionals and others working with children respond when children begin to show or tell about possible abuse can determine whether they continue telling and therefore whether they can be kept safe. Medical professionals can clarify, confuse or contaminate children's accounts, and medical professionals' responses to children can prove crucial in later legal proceedings. This paper challenges the seemingly negative, prohibitive guidance provided to many professionals across health and education about responding to early concerns and instead offers a framework of positive, practical guidance for 'opening doors', based on the approach developed by the team at Triangle over many years. The content of this article and its approach is also applicable to nursing and allied health staff, teachers and professionals working with children within the safeguarding arena. The term 'disclosure' is challenged and reframed. A worked real-life example follows a 6 year old through a sequence of moments where a doctor has opportunities to open or close doors based on clinical experience.
\end{abstract}

\section{INTRODUCTION}

Children are often not heard by health and other professionals when they try to reveal abuse. Triangle is a UK-based, independent organisation that enables children and young people to communicate, particularly in legal proceedings. It offers training, advocacy, investigative interviews, therapy and expert opinion. The 'opening doors', approach has evolved with Triangle's training of forensic interviewers over two decades. The approach itself involves careful, openminded responding, offering an accessible and safe way to explore possible concerns with children, gently at their own pace. ${ }^{1-3}$

\footnotetext{
${ }^{1}$ Triangle Services for Children, Brighton, UK

${ }^{2}$ Community Paediatric Department, Seaside View CDC, Brighton General Hospital, Sussex Community NHS Foundation Trust, Brighton, UK

${ }^{3}$ Department of Paediatric Neurosciences, Evelina Children's hospital, London, UK
}

Correspondence to Dr Jamie Carter, Community Paediatric Dept, Seaside View CDC, Brighton General Hospital, Sussex Community NHS Foundation Trust, Brighton BN2 3EW, UK; Jamie.carter@nhs.net
The aim is to get just enough information to work out what action is required, without leading children or contaminating their accounts. This approach is safe in terms of safeguarding both children and potential evidence. Medical professionals play a crucial role in protecting children from abuse and neglect. We know many children attempt to inform about their abuse, either through verbal allegations, their behaviour or presenting with related medical symptoms. Medical professionals and doctors, as well as other health and education staff,are perceived to advocate for children,are seen as 'trustworthy' by many and can provide children with empathic reassurance. In particular, medical professionals may notice or be told things that other professionals may not, and the way they respond when children begin to show or tell about possible abuse can determine whether they continue telling and therefore whether they can be kept safe. Medical professionals can also clarify, confuse or contaminate children's accounts, and their responses to children can prove crucial in later legal proceedings.

\section{THE CONTEXT}

Children and young people report much higher levels of abuse and neglect than those recorded in official statistics, ${ }^{4-8}$ with recent research suggesting that $85 \%$ of child sexual abuse goes unreported in England. ${ }^{9}$ Contrary to the popular belief that children 'don't tell' about abuse, many adults report telling others as children but not being heard, ${ }^{10} 11$ and research shows that many children do attempt to show (often through their behaviour) or tell over time in different ways. $^{10-13}$

Failure to listen to and consider the voice of the child is a recurrent finding in reviews of professional practice. For example, the serious case review into the murder of Daniel Pelka (at age 4 years) noted that Daniel had become 'invisible' to professionals - 'there is no record of any conversation held with him by any professional about his home life'. ${ }^{14}$ Practitioners should be wary of relying solely on information provided by parents and ensure that the child's views are sought and listened to. ${ }^{15}$
In the UK, regulatory guidance for doctors on protecting children states that doctors: '... must listen to children and young people and talk directly to them, taking into account their age and maturity'. ${ }^{16}$ Similarly, multiagency government guidance states, 'anyone working with children should see and speak to the child, listen to what they say and take their views seriously'. ${ }^{17}$ However well intentioned, such guidance rarely explains how to do this practically, well or safely.

\section{The guidance that can close doors by mistake}

Much guidance for medical and other health and educational professionals focuses on reporting concerns rather than responding to the child. For example, the 2018 campaign by the Department for Education in England states, 'If you think it, report it' and advises professionals to talk to statutory bodies if they are concerned about a child. ${ }^{18}$ There is no mention of talking to the child. Only 4 of 223 pages of guidance for GPs in the UK on safeguarding children mention direct communication with children. ${ }^{19}$

Practitioners in many settings have the understanding that they should adhere to the following 'guidance':

Don't investigate; avoid questions that are leading and suggestive; ask no more questions than are necessary in the circumstances; don't ask any questions at all; don't press the child for information; avoid making promises you can't keep; don't extend a child's account; don't prompt a child; never say you will keep a secret; don't interpret a child's behaviour; don't comment; don't react; don't interrupt; don't express shock or disbelief; don't lead a child as this could prejudice police investigations; never promise the child complete confidentiality; do not question or cross-examine a child; never 'put words into a child's mouth. ${ }^{20}$

The problem is that such guidance could accidentally silence children, by creating anxiety, hesitancy or confusion. While many professionals are clear about what they must not do or say, fewer are confident about what they should do or say.

\section{What research tells us about responding to early concerns}

There is a robust evidence base to inform guidance on responding to early concerns: the best way to elicit accurate information from children is to ask as few questions as possible $^{1121-26}$ and to make these questions short, non-leading and open-ended that trigger recall memory, let the child decide what to focus on and do not introduce any information the child has not mentioned. ${ }^{22}$

The 'opening doors' framework draws on what is known about children's memory and 
children's testimony ${ }^{27-29}$ about the impact of trauma $^{3031}$ and on a set of ideas about nondirective communication. ${ }^{32-34}$

\section{Reframing 'disclosure'}

The 'opening doors' framework does not use the term 'disclosure'. It is not a helpful word in child protection for three reasons: first, 'disclosure' means 'a fact, especially a secret, that is made known'. This assumes that the child has something to tell and that something has happened. It may indeed be that neither are true. Second, 'disclosure' sounds like a one-off, one-way event, where the adult is a passive recipient of words that a child says, instead of an interaction (disclosure or reporting sexual abuse should be considered as a process in many cases). Third, it has a very specific meaning in legal terms that creates further confusion, as it refers to the stage of the litigation process when each party is required to disclose the documents that are relevant to the issues in dispute to the other party.

Use of the word 'disclosure' by professionals has been heavily criticised in a number of recent UK court judgements. This paper reframes 'disclosure' as a twoway interaction and renames 'disclosure' in simpler, more accurate terms; for example, 'She has told the doctor something'; 'He has made an allegation'; 'She has shown very concerning behaviours'; 'He has made worrying comments'.

\section{Positive guidance: Opening doors}

The opening doors guidance is a more positive approach; it guides and advises people what to do rather than what not to do. The guidance combines real life examples of helpful and unhelpful adult responses.

'Opening doors' gives more enabling, helpful and clear guidance on how to respond to children's behaviours or comments that are possibly concerning.

We could say: You are part of children's first line of defence. It is part of your job to build helpful relationships with children. You will meet some children who are not safe. They may tell you, or they may show you. This might happen suddenly, with no warning, or it may happen slowly, bit by bit, over time. It is your job to notice low-level concerning signs,symptoms or behaviours that make you concerned. It is your duty to attend to the things children say or do, that might not initially make sense'.

\section{How to open doors for children: suggestions for professionals}

- If a child tells or shows about possible abuse, listen and attend carefully, even if you look like you are doing something else. Many children find it easier if eye contact is not demanded of them. Let the child tell you what they want to tell you, or show you what they want to show you, as long as they are safe. ${ }^{13}$

- If you are not sure what the child said or did, or if you are not sure what they meant, offer an open invitation, for example, 'tell me more about that' or 'show me that again'. Then say things like 'uhuh' or 'mmhmm' or 'go on' to show you are listening. These are safe things to say because they encourage the child to continue, without directing their account in any way. Saying 'OK' or 'right' or 'yes' is more problematic because these can suggest approval of what the child is telling you, and some things that children need to tell about are really not OK. $^{13}$

- Make it clear through your behaviour and body language that you are comfortable with the situation and that you have time. Give the child as much physical space as they need.

- Adapt your language and communication style in line with the child's needs, being mindful of their developmental stage and age. Be clear about what you need to know.

- Ask one open question at a time. Let the child or young person use his or her own words. Take your time, allow the child time to respond and pause between questions.

- Try to get just enough information to work out what action is required. Make a careful record of what the child said and did and any questions you asked.

- If a child tries to demonstrate violent or sexual acts using your body, say calmly 'I can't let you do that' and if necessary move away.

- If appropriate, reflect back using the child's own words. Say exactly what they said, without expanding or amending or asking questions. If appropriate, comment to show that you have noticed what a child is doing.

- Let the child know what you will do next. This can be very simple: 'I am going to have a think and then I will come back' or perhaps 'A police lady called Jen is going to come and see you. I will stay with you when she's here'.

The aim is to keep opening doors, to keep an open mind about what you see and hear. You may need to carry on opening doors throughout an interaction that may last only a few minutes or be spread across several weeks or months and may involve showing as well as telling.

\section{Opening doors in action}

The real-life scenario below shows this 'dooropening' approach in action, following a child through a sequence of moments where a doctor has opportunities to open or close doors. All these moments are from real examples; however, every child and every situation is different. There is no one right answer, and this is not a script. It is designed to illustrate the principles of open-minded, attentive listening and careful opening of doors.

\section{Scenario}

Becky, age 6 years, has come to see you in clinic with a history of recurrent abdominal pain. You have an experienced children's nurse in the room. Becky is a bright child with no previous health issues, additional needs or known safeguarding concerns. While you are taking the history from her Becky and her mother, Becky appears anxious and wriggles a bit when on the examination couch. From the information you have already and from her presentation you are confident that Becky does not have a serious abdominal condition.

You can make responses that might silence Becky ('close the door') and risk contaminating evidence or make responses that might help 'open the door' for Becky:

Becky wriggles a bit and looks uncomfortable. You respond by giving Becky a quiet, fiddly toy but that risks closing the door. Instead, you might comment calmly, 'you are a bit wriggly' to open the door.

Becky then makes brief eye contact with you and pulls her jeans away from her genital area. You could then say, 'are you sore down there?' and Becky shakes her head. The door is closed.

Instead, you again comment calmly, 'you are pulling your jeans', to which Becky nods, then leans towards you and says quietly, 'it's so ouchy'.

You might then pause asking Becky's mother to tell you about Becky's 'tummy pain', at which point Becky looks away. Instead, you say, 'uhuh' and wait. Becky nods and says, 'really ouchy down there'.

You could close the door by asking her mother if Becky has reported this to anyone; Becky's mother says 'no', and Becky gets up and looks out the window. Instead, you open the door further by saying, 'I'm going to ask Mummy to wait outside for a bit, the nurse will stay here with us'. Becky nods assent and mother other agrees to leave.

In the presence of a chaperone, you say, 'you said it's really ouchy down there. Tell 
me more about that'. This is a very useful, open-ended question. Becky then says, 'the mouse makes it ouchy'. You could then close the door by saying, 'Do you mean a mouse like a pet mouse', with Becky looking out the window in silence again; it would be better to open the door even further, with an enabling 'uhuh, tell me more'.

Becky says, 'Daddy's mouse; it's a secret but my bumbum is so ouchy'. It would be tempting to ask, 'Has daddy touched you down there?' Such a direct question will run the risk of closing the narrative and contaminating the evidence so, instead, you say, 'You told me Daddy's mouse. It's a secret but your bumbum is so ouchy. Thank you for telling me this today Becky, it helps me understand why you may be getting tummy pains and how I can help you'. Becky nods and says, 'in my bed; the mouse needs to come in the hole and play but it's too big and it hurts me'.

That is sufficient narrative to warrant action without further questioning; you say, 'thank you for telling me'. 'I am going to have a think'. 'My job is to help keep you safe'.

\section{CONCLUSION}

This scenario illustrates how, even in a busy outpatient setting, using straightforward, open-ended and enabling questions with the appropriate non-verbal cues can allow the child to provide a narrative that will make her safe, trigger safeguarding intervention and begin the therapeutic support.

This paper, and the approach it is suggesting, addresses some of the seemingly negative, prohibitive guidance on how professionals can respond to children's behaviours and allegations. It is hoped it will provide professionals a challenge to stop, reflect and learn the skills and tools to allow children to feel safe to talk about their experiences, to 'open doors', and in doing so, it is hoped that many more survivors of child sexual abuse will feel better supported, testify and recover.

\section{Twitter Ruth Marchant @RuthMarchant and Jamie} Carter @N/A

Acknowledgements To the children who managed to open doors despite everything. This article is one of a series coauthored by the late RM, intended for different groups of professionals involved in child health. As such, descriptions of the 'Opening Doors' method using similar text can also be found in references 1,2 and 3 . RM was a founding member of Triangle over 20 years ago. She was still one of the directors when she sadly died in December 2018. Ruth was a pioneer in the field of children's rights-specifically the rights of even very young children, or those with complex needs, to give evidence to police and in court, and to be listened to. Through her work with Triangle (www.triangle.org. uk), Ruth developed child-centred approaches that have shifted practice in the criminal justice system and have changed thinking on the ability of children to be compelling and credible witnesses. This guidance is published in her honour.

Contributors CF and JC contributed to this original article authored by RM before she sadly died last year. We provided medical advice and guidance to the original version and $\mathrm{JC}$ updated the final version being submitted. Triangle are aware of this submission and support it and the acknowledgment of RM's role.

Funding The authors have not declared a specific grant for this research from any funding agency in the public, commercial or not-for-profit sectors.

Competing interests None declared.

Patient consent for publication Not required.

Provenance and peer review Commissioned; externally peer reviewed.

(c) Author(s) (or their employer(s)) 2021. No commercial re-use. See rights and permissions. Published by BMJ.

\section{D) Check for updates}

To cite Marchant R, Carter J, Fairhurst C. Arch Dis Child 2021:106:108-110.

Accepted 22 October 2020

Published Online First 24 November 2020

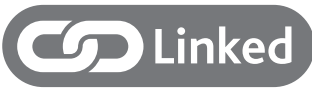

http://dx.doi.org/10.1136/archdischild-2019317033

Arch Dis Child 2021:106:108-110. doi:10.1136/archdischild-2020-320093

ORCID iD

Jamie Carter http://orcid.org/0000-0002-2503-3840

\section{REFERENCES}

1 Marchant P, Fuller J, Phibbs E. Opening Doors. In: $B A C P$ children and young people, 017: 38-43.

2 Marchant R, Turner L. Opening doors. In: Eye, 2017: 54--60

3 Marchant R. Opening doors. In: Horwath J, Platt D, eds. The child's world. 3 edn. London: Jessica Kingsley, 2019: 121-37.

4 Stoltenborgh M, Bakermans-Kranenburg MJ, Lenneke RA, et al. The prevalence of child maltreatment across the globe: review of a series of meta-analyses. Child Abuse Rev 2015;24:37-50.

5 Radford L. Child abuse and neglect in the UK today. London: NSPCC, 2013.

6 Beckett $\mathrm{H}$, Warrington C. Suffering in silence: children and unreported crime. London: Victim Support, 2014.

7 Smith N, Dogaru C, Ellis F. Hear me. believe me. respect me. A survey of adult survivors of child sexual abuse and their experiences of support services, 2015. Available: https://www.uos.ac.uk/sites/default/files/ basic_file/Executive-Summary-Logo-Blk.pdf

8 Allnock D. What evidence exists about the prevalence of child sexual abuse in England and Wales? Evidence briefing for the National policing lead for child protection and abuse investigation. London: Institute of Applied Social Research, 2015.

9 Office of the Children's Commissioner. Protecting children from harm: a critical assessment of child sexual abuse in the family network in England and priorities for action. Children's commissioner: inquiry into child sexual abuse in the family environment; promoting and protecting children's rights 2015:London.

10 McElvaney R. Disclosure of child sexual abuse: delays, non-disclosure and partial disclosure. what the research tells US and implications for practice. Child Abuse Rev. 2015;24:159-69.

11 Allnock D, Miller P. No one noticed no one heard: a study of disclosures of childhood abuse. London: NSPCC, 2013

12 London K, Bruck M, Ceci SJ, et al. Disclosure of child sexual abuse: what does the research tell us about the ways that children tell? Psychology, Public Policy, and Law 2005;11:194-226.

13 Alaggia R. An ecological analysis of child sexual abuse disclosure: considerations for child and adolescent mental health. J Can Acad Child Adolesc Psychiatry 2010;19:32-9

14 Rogers M. Daniel pelka serious case review, coventry children's safeguarding board, 2013. Available: Lgiu.org.uk

15 Plunkett A. Executive summary report: serious case review: Children F, G and H. [S.I.]: NSPCC on behalf of an unnamed local safeguarding children board, 2018.

16 General Medical Council. Protecting children and young people: the responsibilities of all doctors. London: GMC, 2012

17 HM Government. Working together to safeguard children. In: A guide to inter-agency working to safeguard and promote the welfare of children. London: HM Government, 2018

18 HM Government. Anything you notice can help a child at risk. Available: https://tacklechildabuse.campaign.gov.uk

19 RCGP/NSPCC. Safeguarding children toolkit for general practice. London, 2014.

20 Department for Education. What to do if you're worried a child is being abused: advice for practitioners. London: HM Government, 2015.

21 Lamb ME, Hershkowitz I, Orbach Y, et al. Tell me what happened: structured investigative interviews of child victims and witnesses. Chichester, UK: Wiley, 2008.

22 Burrows KS, Powell M. Prosecutors' recommendations for improving child witness statements about sexual abuse. Policing Soc 2014;24:189-207.

23 Lyon TD. Interviewing children. In: Annual review of law and social science. , 2014: 10, 73-89.

24 Malloy LC, Johnson JL, Goodman GS. Children's memory and event reports: The current state of knowledge and best practice. J Forensic socio work 2013;2013:106-32.

25 Orbach Y, Pipe ME. Investigating substantive issues. In: Lamb ME, La Rooy D, Malloy LC, et al, eds. Children's testimony: a handbook of psychological research and forensic practice. 2 edn. Wiley Blackwell, 2011: 147-64.

26 Powell MB, Snow PC. Guide to questioning children during the free-narrative phase of an investigative interview. Aust Psychol 2007;42:57-65.

27 Lamb ME. Children's testimony: a handbook of psychological research and forensic practice. 2 edn. Wiley-Blackwell, 2011.

28 La Rooy D, Heydon G, Korkman J, et al. Interviewing Child Witnesses. In: Oxburgh G, Myklebust T, Grant $\mathrm{T}$, et al, eds. Communication in investigative and legal contexts: integrated approaches from forensic psychology, linguistics and law enforcement. WileyBlackwell, 2015: 57-78.

29 Marchant R. How young is too young? the evidence of children under five in the English criminal justice system. Child Abuse Rev. 2013;22:432-45.

30 Perry B, Szalavitz M. The boy who was raised as a dog and other stories from a child psychiatrist's notebook: what traumatised children can tell us about loss, love and healing. New York: Basic Books, 2006.

31 Van der Kolk B. The body keeps the score: brain, mind, and body in the healing of trauma. Penguin, 2015.

32 Axline V. Play therapy. New York: Ballatine, 1947.

33 Pinney R. Bobby: breakthrough of a special child. McGraw-Hill, 1984.

34 Rogers C. Counselling and psychotherapy. Boston: Houghton Mifflin, 1942. 